\title{
A Variant Primary Structure of Apolipoprotein C-II in Individuals of African Descent
}

\author{
H.-J. Menzel, J. P. Kane, M. J. Malloy, and R. J. Havel \\ Cardiovascular Research Institute, and Department of Medicine, University of California, San Francisco, California 94143
}

\begin{abstract}
We have isolated an isoform of the protein activator of lipoprotein lipase, apolipoprotein C-II, from the very low density lipoproteins of four patients of African ancestry with hypertriglyceridemia and eruptive or pedunculated xanthomata. This protein, which we designate apolipoprotein $\mathrm{C}_{-} \mathrm{II}_{2}$, differs from the previously recognized species, which we denote apolipoprotein $\mathrm{C}-\mathrm{II}_{1}$, by substitution of glutamine for lysine at residue 55 , a mutation which would require only a single-base substitution in the structural gene for apolipoprotein $\mathrm{C}-\mathrm{II}_{1}$. Each of the patients in whom apolipoprotein $\mathrm{C}_{-1 \mathrm{I}_{2}}$ was found had approximately equal amounts of apolipoprotein $\mathrm{C}-\mathrm{II}_{1}$ and apolipoprotein $\mathrm{C}-\mathrm{II}_{2}$ among the apoproteins of the very low density lipoproteins, suggesting that the structural genes for these proteins are allelic. Two additional apparent heterozygotes were found among the first-degree relatives of each of two of the patients in patterns compatible with monogenic autosomal transmission.

Approximately equal amounts of apolipoproteins $\mathbf{C}-\mathrm{II}_{2}$ and C-II 1 were also found by isoelectric focusing in 6 of a casual series of 50 normolipidemic blacks, but none or only trace amounts of apolipoprotein $\mathrm{C}-\mathrm{II}_{2}$ were found in $\mathbf{5 0 0}$ samples from Caucasian subjects with hyperlipidemia. These findings suggest that this polymorphism is distributed primarily among blacks, possibly reflecting some positive Darwinian selection pressure. Whether this polymorphism has a modifying effect upon the development of hyperlipemia remains to be determined.
\end{abstract}

\section{Introduction}

The catabolism of chylomicrons and very low density lipoproteins (VLDL) in plasma depends upon hydrolysis of triglycerides by lipoprotein lipase. Apolipoprotein (apo) ${ }^{1} \mathrm{C}-\mathrm{II}_{1}$, one of the apolipoproteins that is distributed among VLDL, chylomicrons, and high density lipoproteins (HDL), is a requisite cofactor for this enzyme $(1,2)$. This protein constitutes $5-8 \%$ of the mass of the protein moiety of VLDL and 9-15\% of the tetramethylureasoluble apoprotein (3). Its primary structure has been established by classical techniques of protein sequencing $(4,5)$ and by se-

Dr. Menzel's present address is Zentrallaboratorium, Medizinische Einrichtungen, Westfalische Wilhelms Universitat, D-4400 Munster, Federal Republic of Germany.

Address reprint requests to Dr. Kane, 1304-M, University of California, San Francisco, CA 94143.

Received for publication 29 July 1985.

1. Abbreviations used in this paper: apo, apolipoprotein; $\mathrm{CNBr}$, cyanogen bromide.

J. Clin. Invest.

(C) The American Society for Clinical Investigation, Inc.

0021-9738/86/02/0595/07 \$1.00

Volume 77, February 1986, 595-601 quencing of complementary DNA (cDNA) clones $(6,7)$. We have previously reported the isolation of a second isoform of apo C-II from the protein moiety of human serum VLDL by preparative isoelectric focusing (8). This isoform, which we designated apo $\mathrm{C}-\mathrm{II}_{2}$, gave a reaction of identity with the less anionic form of apo C-II first isolated (apo $\mathrm{C}-\mathrm{II}_{1}$ ) in immunodiffusion. We found that the two species activate lipoprotein lipase with equal potency.

We report here the primary structure of apo $\mathrm{C}-\mathrm{II}_{2}$ protein isolated from the plasma of three hyperlipemic subjects of African descent. This protein differs from apo $\mathrm{C}-\mathrm{II}_{1}$ by substitution of a single mole of glutamine for lysine at residue 55 . This isoform is therefore a distinct structural gene product. The mutant gene, which could have been generated by either of two single-base exchanges, appears to be an allele of apo $\mathrm{C}-\mathrm{II}_{1}$, which is the predominant isoform in the Caucasian population. Apo $\mathrm{C}-\mathrm{II}_{2}$ is found in $\sim 12 \%$ of Americans of African ancestry.

\section{Methods}

Characterization of patients and normolipidemic subjects. In a survey of quantitative urea gel electrophoretograms (3) of the apolipoproteins of the lipoproteins of $d<1.006 \mathrm{~g} / \mathrm{cm}^{3}$ in serum obtained from $\sim 500$ hyperlipidemic individuals, four appeared to have one-half or less of the normal content of apo $\mathrm{C}-\mathrm{II}_{1}$. These samples showed prominent apo $\mathrm{C}-\mathrm{II}_{2}$ bands when the apo VLDL were subjected to isoelectric focusing (9). All four patients had severe hyperlipemia, at least intermittently, and all had apo E phenotype E3/2 (10). Their clinical characteristics are presented in Table I, and results of detailed analyses of the apolipoproteins of the $d<1.006 \mathrm{~g} / \mathrm{cm}^{3}$ lipoproteins are shown in Table II. The distributions of the $\mathrm{C}-\mathrm{II}_{2}$ trait and apo $\mathrm{E}$ phenotypes in the kindreds of two probands are presented in Fig. 1.

50 black men and women without history of significant illness were recruited from among the students and staff of the University of California, San Francisco. Blood was drawn after the subjects had fasted overnight. The distribution of cholesterol and triglycerides among VLDL, low density lipoproteins (LDL), and HDL was determined by preparative ultracentrifugation (11), and the distribution of apo $\mathrm{E}$ isoforms was determined by isoelectric focusing $(9,10)$.

Isolation and delipidation of VLDL. Blood was drawn after the patients had fasted 14-16 $\mathrm{h}$ and was allowed to clot at room temperature. The serum was removed immediately by centrifugation. VLDL were isolated by ultracentrifugation as follows. Serum was layered under 10

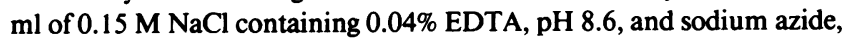
$0.02 \%$ in a 60 Ti rotor (Beckman Instruments, Inc., Palo Alto, CA), and centrifuged at $55 \times 10^{3} \mathrm{rpm}$ for $14 \mathrm{~h}$ at $12^{\circ} \mathrm{C}$. The supernatant VLDL fraction was recentrifuged in a 40.3 rotor for $14 \mathrm{~h}$ at $38 \times 10^{3} \mathrm{rpm}$.

The VLDL were delipidated overnight with $25 \mathrm{vol}$ of 3:1 ethanol/ diethyl ether at $-10^{\circ} \mathrm{C}$. The apolipoproteins were centrifuged down and washed with anhydrous ether.

Isolation of apo $\mathrm{C}-\mathrm{II}_{1}$ and $\mathrm{C}-\mathrm{II}_{2}$. The protein moiety of VLDL was dissolved in $1 \%$ sodium decyl sulfate (Eastman Kodak Co., Rochester, $\mathrm{NY}$ ) in $0.01 \mathrm{M}$ Tris- $\mathrm{HCl}(\mathrm{pH} 8.2)$ to yield a protein concentration of 30 $\mathrm{mg} / \mathrm{ml}$. Apo C-II ${ }_{1}$ and $\mathrm{C}-\mathrm{II}_{2}$ were isolated by preparative isoelectric focusing in a flat-bed apparatus (2117 Multiphor, LKB Produkter AB, Bromma, Sweden) (8). Up to $15 \mathrm{mg}$ of total apo VLDL in decyl sulfate- 


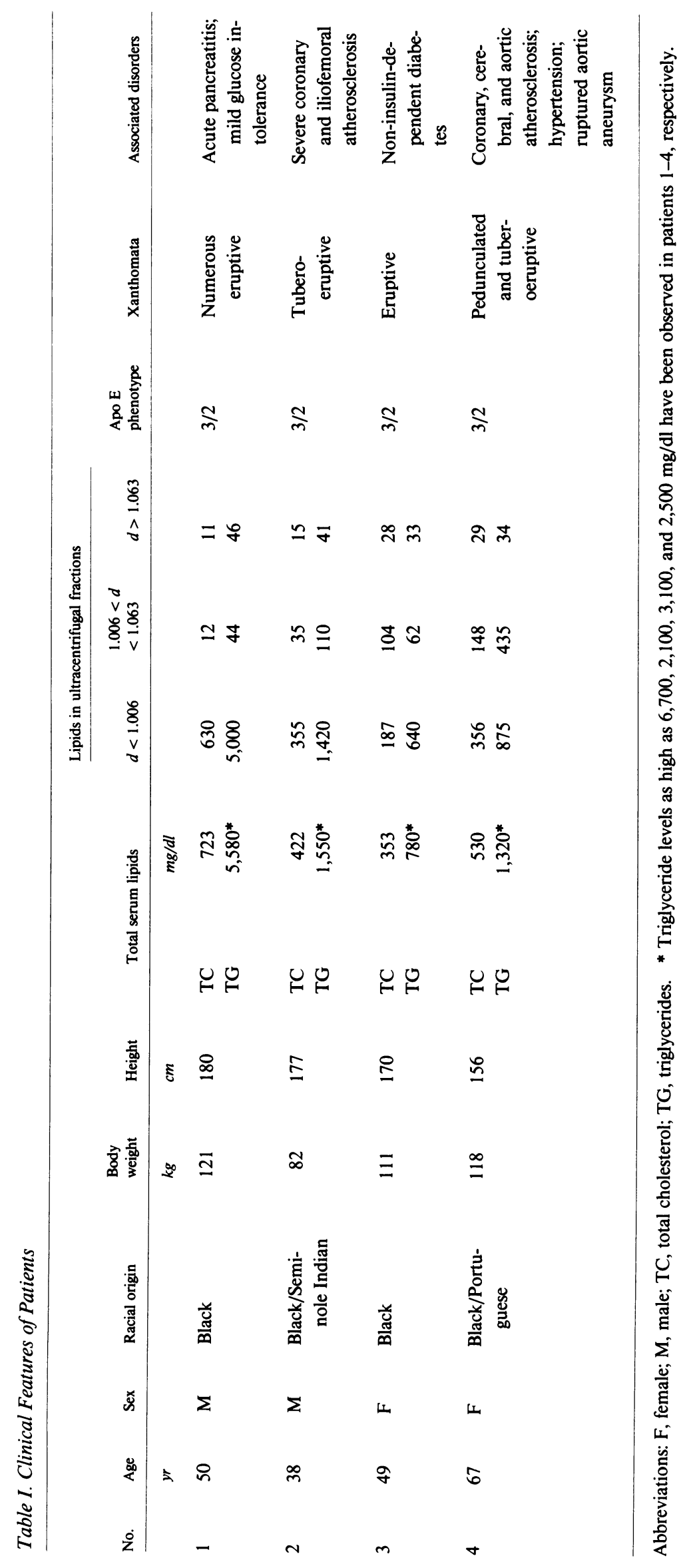


Table II. Apolipoproteins of the $d<1.006 \mathrm{~g} / \mathrm{cm}^{3}$ Lipoproteins

\begin{tabular}{|c|c|c|c|c|c|c|c|c|c|}
\hline \multirow[b]{2}{*}{ Patient } & \multirow[b]{2}{*}{ Apo B } & \multicolumn{7}{|c|}{ Non-B proteins as part of tetramethylurea-soluble protein ${ }^{*}$} & \multirow{2}{*}{$\begin{array}{l}\text { Isoforms of apo E: } \\
\text { Ratio of E3/E2 }\end{array}$} \\
\hline & & C-I & E & C-II & C-III & C-III & C-III ${ }_{2}$ & $\mathrm{C}-\mathrm{III}_{3}$ & \\
\hline & $\%$ & $\%$ & $\%$ & $\%$ & $\%$ & $\%$ & $\%$ & $\%$ & \\
\hline 1 & 52 & 1.7 & 21.1 & 5.4 & 3.5 & 30.5 & 27.3 & 10.3 & 0.70 \\
\hline 2 & 46 & 10.4 & 31.1 & 4.7 & 2.0 & 33.4 & 17.0 & 1.5 & 0.79 \\
\hline 3 & 52 & 6.3 & 20.8 & 6.8 & 2.3 & 34.1 & 25.3 & 4.4 & 1.07 \\
\hline 4 & 45 & 2.3 & 9.1 & 5.2 & 1.8 & 37.4 & 38.0 & 6.1 & 0.79 \\
\hline
\end{tabular}

* Analyzed as in Kane et al. (3); mean of duplicates. $\ddagger$ Analyzed as in Havel et al. (10); apolipoproteins were reduced with 2-mercaptoethanol; mean of duplicates. Apo C- $\mathrm{II}_{2}$ is incompletely resolved from apo $\mathrm{C}$ - $\mathrm{III}_{1}$ by this technique; therefore, it contributes to the total area included in the $\mathrm{C}-\mathrm{III}$, band. Apo E-4 was absent in all samples; the E3/E2 ratio indicates that the phenotype of all patients is E3/2 (10).

Tris buffer was applied. After focusing was completed the individual bands were excised and the protein was extracted with $0.5 \%$ decyl sulfate, $0.01 \mathrm{M}$ Tris, $\mathrm{pH}$ 8.2. After elution each species appeared as a single band of appropriate $\mathrm{pI}$ on analytical isoelectric focusing (8). To remove ampholines and decyl sulfate, the proteins were precipitated by addition of $40 \%$ trichloracetic acid (TCA) to a final concentration of $10 \%$. After 30 min at $0^{\circ} \mathrm{C}$ the TCA was removed by centrifugation and the precipitate was washed similarly three times with $10 \%$ TCA at $0^{\circ} \mathrm{C}$. TCA was removed from the precipitate by a 30 -min exposure to acetone at $0^{\circ} \mathrm{C}$. For analytical isoelectric focusing, protein was dissolved in $1 \%$ decyl

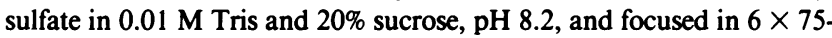
$\mathrm{mm}$ polyacrylamide gels between $\mathrm{pH} 3.5$ and 7.0 (8).

Cleavage of proteins with cyanogen bromide. Apo C-II species were dissolved in $70 \%$ formic acid and incubated with a 500 -fold molar excess of cyanogen bromide (CNBr) (Sigma Chemical Co., St. Louis, MO), over methionine, for $24 \mathrm{~h}$ at $23^{\circ} \mathrm{C}$ (12). The resulting fragments were lyophilized, dissolved in $70 \%$ formic acid, and separated on a $0.6 \times 120$ $\mathrm{cm}$ column of polyacrylamide gel beads (P30, Bio-Rad Laboratories, Richmond, CA) in $25 \%$ formic acid. Three peaks were obtained as described by Jackson et al. (4). Protein from the first peak was lyophilized in preparation for tryptic digestion.

Tryptic digestion. Trypsin treated with $n$-tosyl-L-phenylalanine chloromethyl ketone to inhibit chymotryptic activity (Worthington Biochemical Corp., Freehold, NJ) was incubated for $16 \mathrm{~h}$ at $37^{\circ} \mathrm{C}$ with apolipoproteins or their $\mathrm{CNBr}$ fragments, dissolved in $0.1 \mathrm{M}\left(\mathrm{NH}_{4}\right) \mathrm{HCO}_{3}$
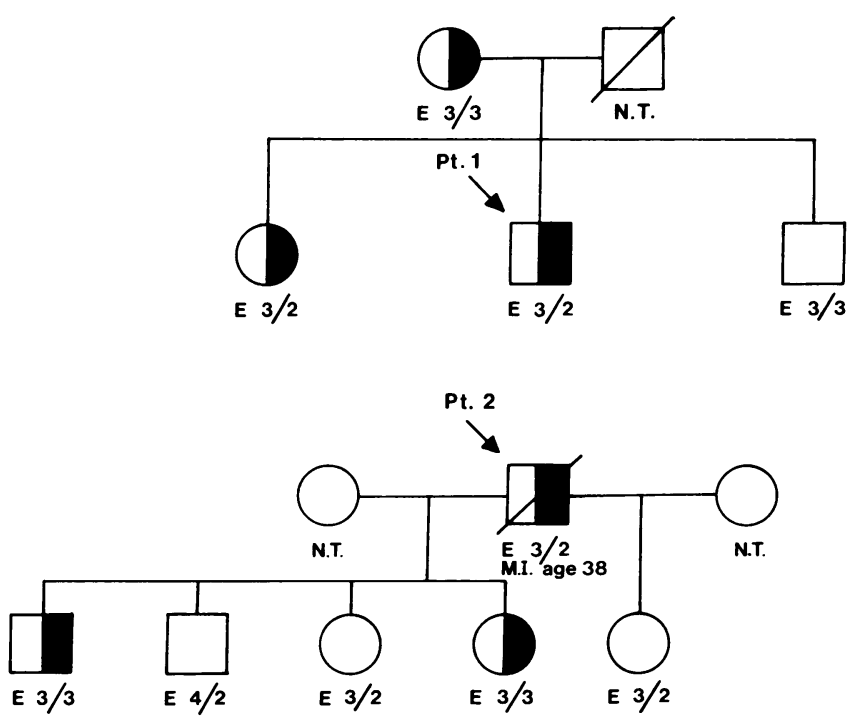

Figure 1. Distribution of the apo $\mathrm{C}-\mathrm{II}_{2}$ trait and apo $\mathrm{E}$ phenotypes in two kindreds with hyperlipidemic probands. containing $0.02 \mathrm{NaN}_{3}(\mathrm{pH} 7.7)$ at an enzyme-protein ratio of $1: 100$ $(w t / w t)$. Substrate proteins were present at a concentration of $5 \mathrm{mg} / \mathrm{ml}$.

Two-dimensional peptide mapping. Tryptic peptides were separated by thin-layer chromatography on cellulose (Merck \& Co., Inc., Rahway, $\mathrm{NJ})(13) .1-10 \mu \mathrm{l}$ were applied to $10 \times 10-\mathrm{cm}$ sheets and chromatographed with isobutanol/pyridine/acetic acid/ $\mathrm{H}_{2} \mathrm{O}$ (30:21:9:24). The plates were dried with warm air, sprayed with electrophoresis buffer $\left(\mathrm{H}_{2} \mathrm{O} /\right.$ pyridine/ acetic acid/isobutanol; 225:25:1:2), and subjected to electrophoresis at right angles to the chromatography, with a field potential of $500 \mathrm{~V}$, at $6^{\circ} \mathrm{C}$. Methyl green was used as a marker. The plates were air-dried and sprayed with a solution of $0.1 \mathrm{~g}$ of ninhydrin (Pierce Chemical Co., Rockford, IL) in $60 \mathrm{ml}$ of ethanol, $20 \mathrm{ml}$ of acetic acid, and $8 \mathrm{ml}$ of collidine. Color of peptide spots was developed in $2-5 \mathrm{~min}$ at $80^{\circ} \mathrm{C}(14)$.

Preparative thin-layer mapping. The preparative separation technique employed the same buffers, cellulose layers, and voltage described above, except that the plates were $20 \times 20 \mathrm{~cm} .40-60 \mu \mathrm{l}$ of solution were applied per plate. A concentration of ninhydrin one-tenth that used in mapping above was employed to minimize degradation of the peptides. Cellulose at each spot was scraped from the plates. The peptides were eluted with $0.02 \mathrm{M} \mathrm{N}$-ethylmorpholine, $\mathrm{pH} 8.2$, containing $0.02 \% \mathrm{NaN}_{3}$ for amino acid analysis.

Amino acid analysis. Peptide samples were deaerated by alternate freezing and thawing in $6 \mathrm{~N} \mathrm{HCl}$ (Ultrex, J. T. Baker Chemical Co., Phillipsburg, NJ), and hydrolyzed in vacuo for $22 \mathrm{~h}$ at $110^{\circ} \mathrm{C}$ with $0.05 \%$ phenol. Enzymic hydrolysis was carried out by incubation of one part of pronase (Sigma Chemical Co.) with 100 parts by weight of peptide, for $16 \mathrm{~h}$ at $37^{\circ} \mathrm{C}(15)$. Pronase activity was eliminated by heating to $60^{\circ} \mathrm{C}$ for $30 \mathrm{~min}$. Final degradation of the peptides was accomplished by incubation with amino peptidase M (Sigma Chemical Co.) (1:100, $\mathrm{wt} / \mathrm{wt})$ for $24 \mathrm{~h}$ at $37^{\circ} \mathrm{C}(16)$.

Hydrolysates were lyophilized and dissolved in $0.2 \mathrm{M}$ sodium citrate (pH 2.2) for analysis with a two-column program on a Beckman model 121-M amino acid analyzer (17).

\section{Results}

The apo $\mathrm{C}-\mathrm{II}_{2}$ gene and the apo E2 gene did not cosegregate in the two patients' kindreds that were available for study (Fig. 1). It is probable that these genes are present on separate chromosomes, most likely members of a homologous pair, because the structural genes for both apo $\mathrm{E}$ and apo $\mathrm{C}-\mathrm{II}_{1}$ have been mapped to chromosome 19 (4). However, a nonallelic site for the apo $\mathrm{C}-\mathrm{II}_{2}$ structural gene is equally compatible with these patterns of transmission.

Maps of tryptic peptides of apo $\mathrm{C}-\mathrm{II}_{1}$ contained seven distinct ninhydrin-reactive spots which we designate A-G (Fig. 2). In contrast, the peptides designated $\mathrm{D}$ and $\mathrm{F}$ were absent from maps of apo $\mathrm{C}-\mathrm{II}_{2}$ (Fig. 2). Identical maps were obtained with apo 


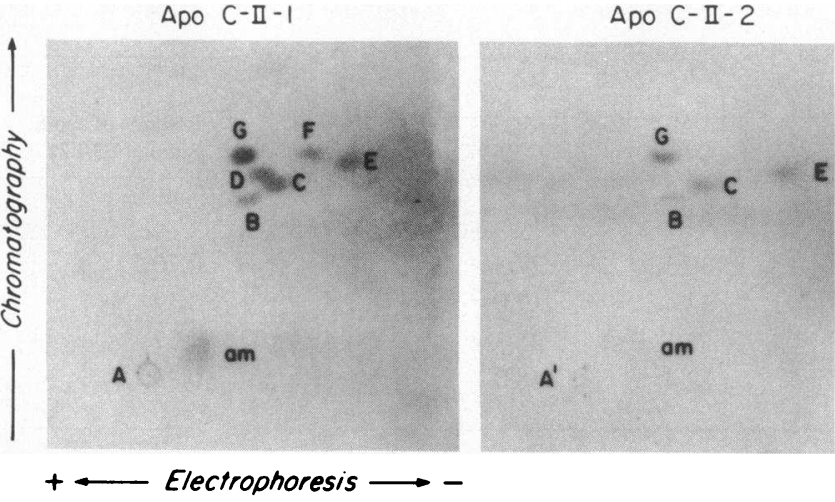

Figure 2. Two-dimensional maps of tryptic peptides from apo $\mathrm{C}-\mathrm{II}_{1}$ and apo $\mathrm{C}-\mathrm{II}_{2}$, respectively, from patient 1 .

C-II ${ }_{2}$ from patients $1-3$, described above, who had hyperlipidemia associated with partial deficiency of apo C-- $\mathrm{II}_{1}$. Amino acid analysis of the peptides recovered from the preparative two-dimensional plates allowed us to establish their identities with reference to the tryptic peptides described by Jackson et al. (4) (Fig. 3 , Table III). In our experiments cleavage apparently did not occur at the lysine at residue 76 , so that the sequences corresponding to peptides 7 and 8 of Jackson et al. remained conjoined. In the case of apo $\mathrm{C}-\mathrm{II}_{1}$, the A peptide, which remains at the point of application to the thin-layer plate, contains the appropriate molar ratios of amino acids for the conjoined peptides 7 and 8 (residues 56-79). Our peptide D corresponds to peptide T- 6 and our peptide $F$ corresponds to the sequence of residues 49-55, or peptides T-5 and T- 6 conjoined, because of failure to cleave at the arginine residue at position 50 (Figs. 2 and 3; Table III). In the case of apo $\mathrm{C}_{-} \mathrm{II}_{2}$, a reduced amount of peptide $T-5$ was seen and peptides $T-6, T-7$, and $T-8$ were not produced. However, a peptide containing the whole sequence of residues 49-79, which we designate $A^{\prime}$, is found at the point of application. Its amino acid composition after acid hydrolysis is appropriate for this sequence with the exception that it contains one less residue of lysine and one more residue of glutamate than would be predicted from the sequence of $\mathrm{C}-\mathrm{II}_{1}$. These results are compatible with a single amino acid substitution of glutamic acid or glutamine for lysine at position 55, a mutation which would eliminate the cleavage site at that point, as we observed. The amino acid compositions of the remaining peptides, with unchanged mapping loci, were identical in both apo $\mathrm{C}-\mathrm{II}_{1}$ and apo $\mathrm{C}-\mathrm{II}_{2}$, indicating that the difference between the proteins is confined to a single tryptic peptide. Thus, peptides B, C, and E correspond to tryptic peptides $T-1, T-3$, and $T-5$, respectively (4), whereas peptide $G$ appears to contain both the T-2 and T4 peptides.

To define further the difference between the two forms of apo C-II, we studied the $\mathrm{CNBr}$ fragments of each, prepared from the VLDL of patient 1. The apparent pl's of the principal peptide, corresponding to CNBr I of Jackson (4), are clearly different upon isoelectric focusing (Fig. 4), indicating that this fragment contains the region in which the difference between the two forms of apo C-II occurs. Mapping of the tryptic peptides derived from this fragment was also informative (Figs. 3 and 5). In the case of apo C-II $I_{1}$, peptide B is absent as would be expected, and two new peptides, $\mathrm{H}$ and $\mathrm{I}$, appeared, as would be predicted from the sequence of the protein. There was some contamination of peptide I by small amounts of peptide B, reflecting some incompleteness of $\mathrm{CNBr}$ cleavage at position 9. Because peptide B contains several amino acids which are absent from the I segment (residues 56-60), the composition of the latter could be arrived at subtractively. The tryptic fragments derived from the

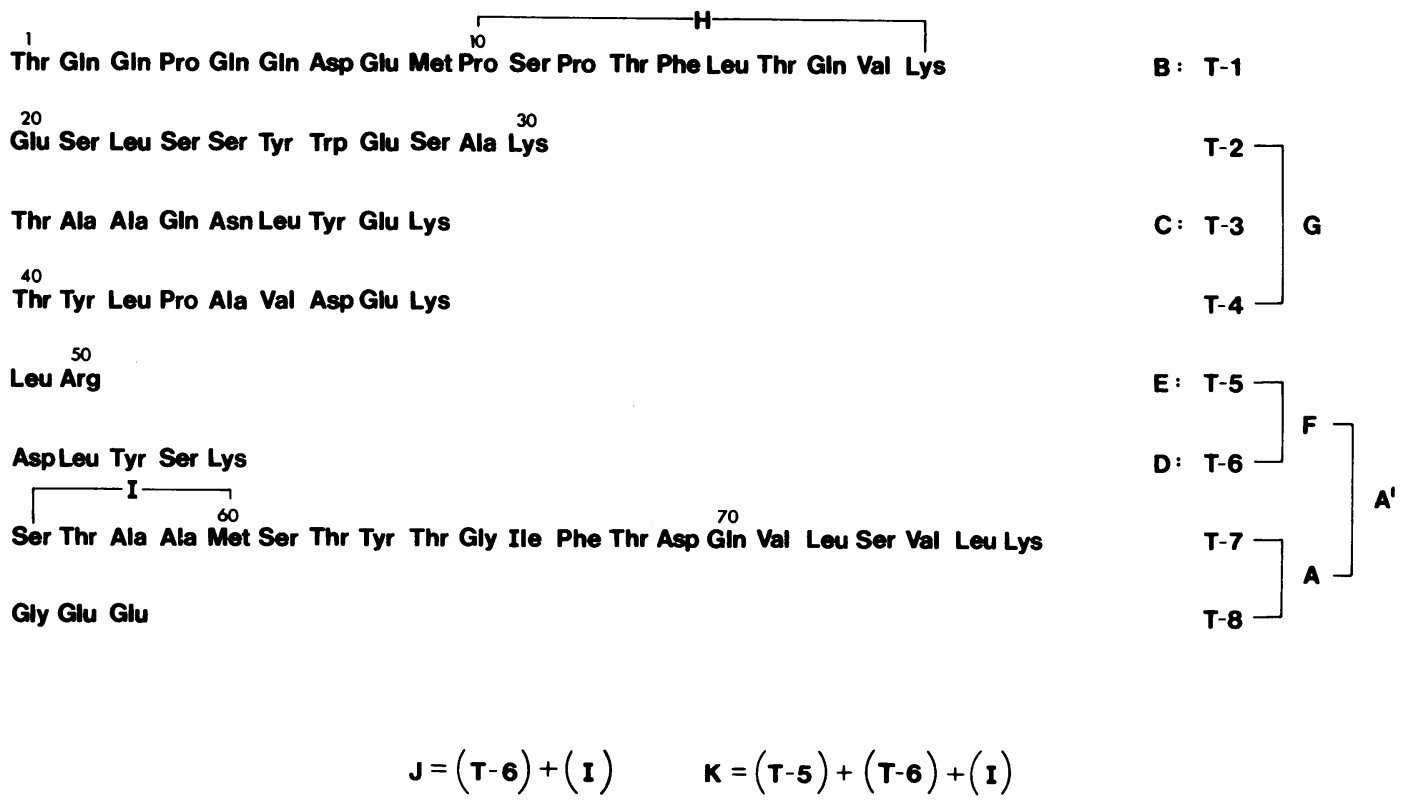

Figure 3. The primary sequence of apo $\mathrm{C}-\mathrm{II}_{1}$. B, C, and E indicate tryptic peptides common to both apo $\mathrm{C}-\mathrm{II}_{1}$ and apo $\mathrm{C}-\mathrm{II}_{2}$. $\mathrm{G}$ indicates the two tryptic peptides (T-2 and T-4) that migrate to the same locus in our peptide maps. $D$ indicates peptide $T-6$ and bracket $F$ denotes the uncleaved sequence of residues 49-55, both of which are seen only

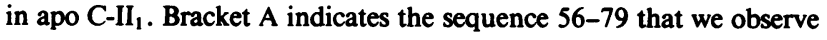

in tryptic digests of apo $\mathrm{C}-\mathrm{II}_{1}$, and $\mathrm{A}^{\prime}$ indicates the sequence 49-79 seen in tryptic digests of apo $\mathrm{C}-\mathrm{II}_{2}$. The sequence 10-60, liberated by $\mathrm{CNBr}$ cleavage, is the $\mathrm{CNBr}$ I peptide. Subsequent tryptic digestion of this fragment yields segment $\mathrm{H}$ in both proteins and segment $\mathrm{I}$ in $\mathrm{C}-\mathrm{II}_{1}$ only. 
Table III. Amino Acid Analysis of Tryptic Peptides Derived from Apo C-II ${ }_{1}$ and Apo C-II

\begin{tabular}{|c|c|c|c|c|c|c|c|c|c|c|c|c|c|c|c|c|c|c|c|c|}
\hline $\begin{array}{l}\text { Amino } \\
\text { acid }\end{array}$ & $\begin{array}{l}\text { C-II } \\
\text { A }\end{array}$ & $\begin{array}{l}T-7 \\
+T-8\end{array}$ & $\begin{array}{l}\mathrm{C}-\mathrm{II}_{2} \\
\mathrm{~A}\end{array}$ & $\begin{array}{l}T-5+T-6 \\
+T-7+T-8\end{array}$ & $\begin{array}{l}\text { C-II } \\
\text { B }\end{array}$ & T-1 & $\begin{array}{l}\mathrm{C}-\mathrm{II}_{2} \\
\mathrm{~B}\end{array}$ & $\begin{array}{l}\mathrm{C}-\mathrm{II}_{\mathbf{1}} \\
\mathrm{C}\end{array}$ & $\mathrm{T}-3$ & $\begin{array}{l}\mathrm{C}-\mathrm{II}_{2} \\
\mathrm{C}\end{array}$ & $\begin{array}{l}\text { C-III } \\
\text { D }\end{array}$ & T-6 & $\begin{array}{l}\text { C-III } \\
\text { E }\end{array}$ & T.5 & $\begin{array}{l}\mathrm{C}-\mathrm{II}_{2} \\
\mathrm{E}\end{array}$ & $\begin{array}{l}\text { C-III } \\
\text { F }\end{array}$ & $\begin{array}{l}T-5 \\
+T-6\end{array}$ & $\begin{array}{l}\text { C-II } \\
\text { G }\end{array}$ & $\begin{array}{l}\mathrm{T}-2 \\
+\mathrm{T}-4\end{array}$ & $\begin{array}{l}\text { C-II } \\
\text { G }\end{array}$ \\
\hline & \multicolumn{20}{|c|}{ moles/mole of peptide } \\
\hline Lys & 0.90 & 1 & 1.22 & 2 & 0.96 & 1 & 0.89 & 0.78 & 1 & 0.84 & 0.99 & 1 & & & & 1.03 & 1 & 2.12 & 2 & 1.65 \\
\hline His & & & & & & & & & & & & & & & & & & & & \\
\hline Arg & & & 0.77 & 1 & & & & & & & & & 1.16 & 1 & 1.15 & 1.10 & 1 & & & \\
\hline Asp & 1.15 & 1 & 2.25 & 2 & 1.14 & 1 & 0.89 & 1.05 & 1 & 1.09 & 0.89 & 1 & & & & 1.23 & 1 & 1.12 & 1 & 1.09 \\
\hline Thr & 4.00 & 4 & 4.33 & 4 & 3.11 & 3 & 2.99 & 0.81 & 1 & 0.80 & & & & & & & & 0.84 & 1 & 0.74 \\
\hline Ser & 3.02 & 3 & 4.09 & 4 & 0.92 & 1 & 0.98 & & & & 0.94 & 1 & & & & 0.87 & 1 & 3.38 & 4 & 3.81 \\
\hline Glu & 2.58 & 3 & $\underline{3.96}$ & $\underline{3}$ & 5.75 & 6 & 6.04 & 2.22 & 2 & 2.09 & & & & & & & & 2.91 & 3 & 2.75 \\
\hline Pro & & & & & 3.02 & 3 & 3.05 & & & & & & & & & & & 0.90 & 1 & 1.00 \\
\hline Gly & 1.89 & 2 & 2.24 & 2 & & & & & & & & & & & & & & & & \\
\hline Ala & 1.71 & 2 & 2.10 & 2 & & & & 2.06 & 2 & 2.14 & & & & & & & & 2.05 & 2 & 2.24 \\
\hline Val & 2.04 & 2 & 2.10 & 2 & 0.83 & 1 & 0.89 & & & & & & & & & & & 0.93 & 1 & 0.86 \\
\hline Met & 0.30 & 1 & 0.20 & $i$ & 0.40 & 1 & 0.68 & & & & & & & & & & & & & \\
\hline Ileu & 1.10 & 1 & 0.89 & 1 & & & & & & & & & & & & & & & & \\
\hline Leu & 2.12 & 2 & 3.50 & 4 & 1.01 & 1 & 1.10 & 1.09 & 1 & 1.06 & 1.11 & 1 & 0.84 & 1 & 0.84 & 2.04 & 2 & 2.07 & 2 & 2.27 \\
\hline Tyr & 1.03 & 1 & 1.82 & 2 & & & & 1.04 & 1 & 0.98 & 1.11 & 1 & & & & 1.08 & 1 & 1.91 & 2 & 2.07 \\
\hline Phe & 0.92 & 1 & 0.96 & 1 & $0.28^{*}$ & 1 & 0.80 & & & & & & & & & & & & & \\
\hline Trp & & & & & & & & & & & & & & & & & & ND & 1 & ND \\
\hline
\end{tabular}

All values are means of two separate preparations from patient 1 . Underlined values differ by 1 mol from expected values for apo C-II ${ }_{1}{ }^{*}$ Phenol omitted during hydrolysis.

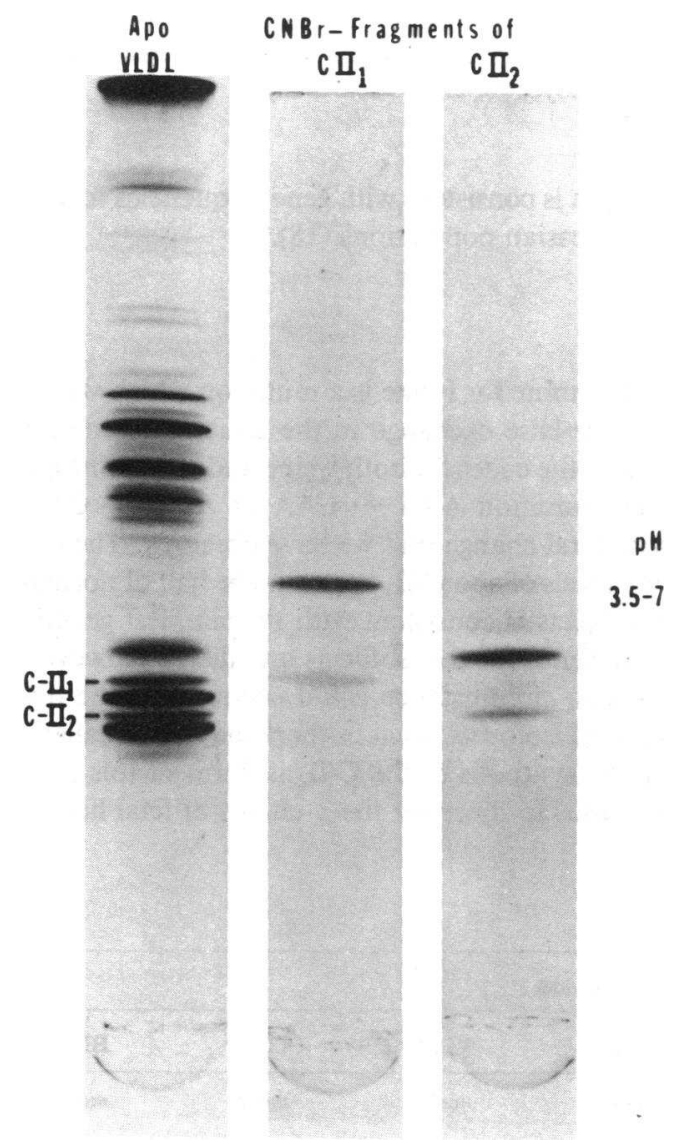

Figure 4. Analytical isoelectric focusing of whole apo VLDL from patient 1 (left) and of the $\mathrm{CNBr}$ peptides of apo $\mathrm{C}-\mathrm{II}_{1}$ and apo $\mathrm{C}$ - $\mathrm{II}_{2}$, respectively, (center and right). The principal band in each of the latter two is CNBr I.
$\mathrm{CNBr}$ I fragment of apo $\mathrm{C}-\mathrm{II}_{2}$ also contained peptide $\mathrm{H}$, indicating that these regions are similar in the two isoforms. However, peptide I was missing and two different peptides designated $\mathbf{J}$ and $\mathrm{K}$ appeared. Amino acid analysis of these peptides (Table IV) showed that peptide $J$ could be identified as the T-6 peptide, plus the I segment (residues 51-60 overall) and peptide $K$ as the equivalent of T-5, T-6, and the I segment (residues 49-60 overall), except that each contained one residue of glutamate and essentially no lysine. This is again evidence for substitution of glutamic acid or glutamine for lysine somewhere between residues 49 and 60 . To determine whether glutamic acid or glutamine is the substituted element, we subjected peptides $J$ and $K$ to enzymic hydrolysis which, in contrast to acid hydrolysis, would not remove the amide group from glutamine. This resulted in the appearance of an additional mole of amino acid at the point where serine normally appears, and where we found glutamine

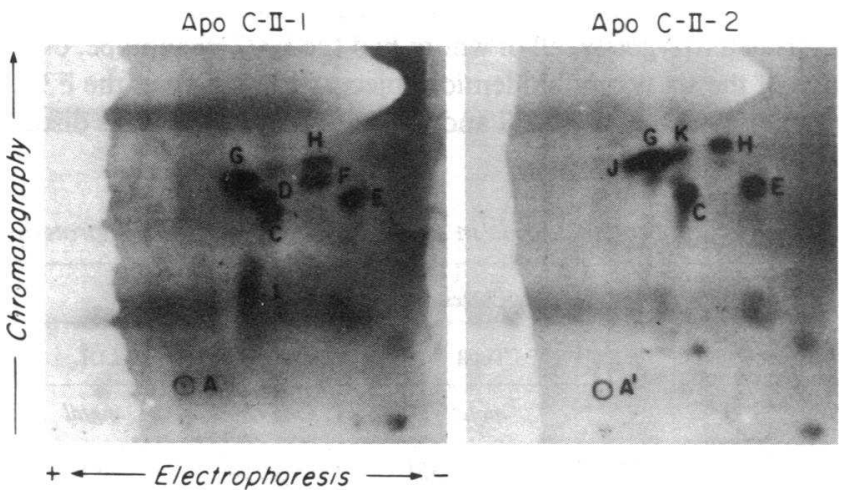

Figure 5. Two-dimensional peptide maps of the tryptic peptides derived from the $\mathrm{CNBr}$ I fragment of apo $\mathrm{C}-\mathrm{II}_{1}(l e f t)$ and apo $\mathrm{C}-\mathrm{II}_{2}$ (right). 


\begin{tabular}{|c|c|c|c|c|c|c|c|c|c|c|c|}
\hline \multirow[b]{2}{*}{ Amino acid } & \multicolumn{5}{|c|}{ Acid hydrolysis } & \multicolumn{6}{|c|}{ Enzymatic hydrolysis } \\
\hline & \multirow{2}{*}{$\begin{array}{l}\text { C-II } \mathrm{H} \\
\begin{array}{l}\text { moles/ } \\
\text { mole of } \\
\text { peptide }\end{array}\end{array}$} & $\begin{array}{l}\text { Segment } \\
10-13\end{array}$ & \multirow{2}{*}{$\begin{array}{l}\mathrm{C}-\mathrm{II}_{2} \mathrm{H} \\
\text { moles/ } \\
\text { mole of } \\
\text { peptide }\end{array}$} & \multirow{2}{*}{$\begin{array}{l}\mathrm{C}-\mathrm{II}_{2} \mathrm{~J} \\
\text { moles } / \\
\text { mole of } \\
\text { peptide }\end{array}$} & \multirow{2}{*}{$\begin{array}{l}\text { T-6 + residues } \\
56-60\end{array}$} & \multirow{2}{*}{$\begin{array}{l}\mathrm{C}-\mathrm{II}_{2} \mathrm{~K} \\
\text { moles/ } \\
\text { mole of } \\
\text { peptide }\end{array}$} & $\begin{array}{l}\text { T-5; T-6 } \\
+ \text { residues } \\
56-60\end{array}$ & $\mathrm{C}-\mathrm{II}_{2} \mathrm{~J}$ & $\begin{array}{l}\text { T-6 + residues } \\
56-60\end{array}$ & $\mathrm{C}-\mathrm{II}_{2} \mathrm{~K}$ & $\begin{array}{l}\text { T- } 5+\text { T- } 6 \\
+ \text { residues } \\
56-60\end{array}$ \\
\hline & & $\begin{array}{l}\text { moles/ } \\
\text { mole of } \\
\text { peptide }\end{array}$ & & & & & $\begin{array}{l}\text { moles/ } \\
\text { mole of } \\
\text { peptide }\end{array}$ & $\begin{array}{l}\text { moles/ } \\
\text { mole of } \\
\text { peptide }\end{array}$ & $\begin{array}{l}\text { moles/ } \\
\text { mole of } \\
\text { peptide }\end{array}$ & $\begin{array}{l}\text { moles/ } \\
\text { mole of } \\
\text { peptide }\end{array}$ & $\begin{array}{l}\text { moles/ } \\
\text { mole of } \\
\text { peptide }\end{array}$ \\
\hline Lys & 0.84 & 1 & 0.91 & $\underline{0.11}$ & $\underline{1}$ & $\underline{0.11}$ & $\underline{1}$ & $\underline{0.0}$ & $\underline{1}$ & $\underline{0.0}$ & $\underline{1}$ \\
\hline \multicolumn{12}{|l|}{ His } \\
\hline Arg & & & & & & 1.06 & 1 & & & 1.04 & 1 \\
\hline Asp & & & & 0.89 & 1 & 1.11 & 1 & $0.0 \ddagger$ & 1 & 0.0 & 1 \\
\hline Thr & 2.09 & 2 & 2.14 & 1.01 & 1 & 1.10 & 1 & 1.11 & 1 & 0.38 & 1 \\
\hline Ser & 0.95 & 1 & 0.93 & 1.90 & 2 & 2.02 & 2 & $\underline{2.67}$ & $\underline{2 \S}$ & $\underline{2.79}$ & $\underline{2 \S}$ \\
\hline Glu & 1.15 & 1 & 0.91 & $\underline{1.02}$ & $\underline{0}$ & $\underline{1.06}$ & $\underline{0}$ & 0.0 & $0 \S$ & 0.0 & $0 \S$ \\
\hline Pro & 1.87 & 2 & 2.08 & & & & & & & & \\
\hline \multicolumn{12}{|l|}{ Gly } \\
\hline Ala & & & & 2.09 & 2 & 2.16 & 2 & 2.28 & 2 & 2.08 & 2 \\
\hline Val & 1.07 & 1 & 0.90 & & & & & & & & \\
\hline Met & & & & 0.53 & 1 & 0.22 & 1 & 0.81 & 1 & 0.88 & 1 \\
\hline \multicolumn{12}{|l|}{ Ileu } \\
\hline Leu & 1.00 & 1 & 1.16 & 1.13 & 1 & 1.68 & 2 & $0.08 \ddagger$ & 1 & 1.67 & 2 \\
\hline Tyr & & & & 0.96 & 1 & 0.99 & 1 & 1.14 & 1 & 1.21 & 1 \\
\hline Phe & 1.00 & 1 & 1.00 & & & & & & & & \\
\hline Trp & & & & & & & & & & & \\
\hline
\end{tabular}

* All values for acid hydrolysates are means of two separate preparations and values for enzymatic hydrolysis are single preparations from patient 1. Underlined values differ by $\sim 1 \mathrm{~mol}$ from expected values for apo C-II . $\ddagger$ Aspartyl leucine apparently not cleaved. $\S$ After enzymic hydrolysis, glutamine amide nitrogen remains intact. Glutamine coelutes with serine in the program employed for amino acid analysis.

to be eluted when it is chromatographed by our analyzer program. We therefore conclude that substitution of glutamine for Iysine at position 55 is the cause of the polymorphism of apo C-II described here.

All of the 50 control subjects were normolipidemic. Six were found to have bands corresponding to apo $\mathrm{C}-\mathrm{II}_{1}$ and apo $\mathrm{C}-\mathrm{II}_{2}$ of equal intensity on isoelectric focusing of the apolipoproteins of VLDL. Of the remainder 42 had no visible apo $\mathrm{C}-\mathrm{II}_{2}$ band and two had only traces of a band with appropriate pI for apo $\mathrm{C}-\mathrm{II}_{2}$. The total serum cholesterol and triglyceride levels and the cholesterol and triglyceride contents of ultracentrifugal fractions of serum in the apo $\mathrm{C}-\mathrm{II}_{1}$ and $\mathrm{C}-\mathrm{II}_{2}$ groups are shown in Table V. No significant differences were found in any of these values. In comparison with the four hyperlipidemic patients with $\mathrm{C}-\mathrm{II}_{2}$ heterozygosity, all of whom had the E3/2 phenotype, only one of the six normolipidemic subjects with $\mathrm{C}-\mathrm{II}_{2}$ had the E3/2 phenotype. One had E4/3 and the remainder E3/3. This distri- bution of phenotypes is consistent with gene frequencies for the apo $\mathrm{E}$ alleles in Caucasian populations (18).

\section{Discussion}

Substitution of glutamine for lysine is a mutation which would require only a single-base exchange in the structural gene for the protein. Because the codes for both lysine and glutamine are degenerate, either mutation AAA $\rightarrow$ CAA or AAG $\rightarrow$ CAG produces the structural change that we have observed. The observation that the levels of apo C-II ${ }_{1}$ appear to be half of normal or less in these subjects is consistent with the simplest genetic model, in that the genes for the isoforms are allelic. However, an additional genetic circumstance could account for the observed distribution of isoforms. That is, there may be nonallelic genes governing the synthesis of the $\mathrm{C}-\mathrm{II}_{2}$ isoform of this apolipoprotein, analogous to those for the $\gamma$-chains of fetal hemo-

Table V. Lipoprotein Lipids in Black Patients with Apolipoproteins $\mathrm{C}-\mathrm{II}_{1}$ and $\mathrm{C}-\mathrm{II}_{2}$

\begin{tabular}{|c|c|c|c|c|c|c|c|c|}
\hline \multirow[b]{2}{*}{ Subjects } & \multicolumn{4}{|l|}{ Cholesterol } & \multicolumn{4}{|c|}{ Triglycerides } \\
\hline & Total & VLDL & LDL & HDL & Total & VLDL & LDL & HDL \\
\hline & $m g / d l$ & $m g / d l$ & $m g / d l$ & $m g / d l$ & $m g / d l$ & $m g / d l$ & $m g / d l$ & $m g / d l$ \\
\hline C-II $1 / C-I_{1}(n=44)$ & $199 \pm 36^{*}$ & $13 \pm 16$ & $111 \pm 33$ & $62 \pm 14$ & $90 \pm 84$ & $49 \pm 76$ & $20 \pm 7$ & $17 \pm 7$ \\
\hline $\mathrm{C}-\mathrm{II}_{1} / \mathrm{C}-\mathrm{II}_{2}(n=6)$ & $189 \pm 32$ & $12 \pm 6$ & $106 \pm 27$ & $62 \pm 13$ & $92 \pm 49$ & $42 \pm 23$ & $27 \pm 17$ & $21 \pm 15$ \\
\hline
\end{tabular}

* \pm standard deviation. 
globin $(19,20)$. These additional genes, which code for proteins differing from the principal gene product by a single-point substitution, contribute increased amounts of $\gamma$-chain in the face of anemia. The expression of such nonallelic genes might be called forth when the synthesis of the normal C-II isoform is curtailed by some primary genetic or metabolic process. Such a mechanism is consistent with the observation that trace amounts of apoprotein with an isoelectric point indistinguishable from that of $\mathrm{C}_{-} \mathrm{II}_{2}$ protein occasionally appear in apo VLDL.

Our previous observation tht the $\mathrm{C}-\mathrm{II}_{2}$ apoprotein possesses normal ability to activate lipoprotein lipase was made on protein isolated from the VLDL of patient $3(8)$. Therefore, it appears that lysine residue 55 is not critical to the activation of the lipoprotein lipase system, despite evidence that this residue is included in a segment of the protein in which the activator property residues (21).

The total content of apo C-II appears to be diminished in the VLDL of our hyperlipidemic patients, as it is in most hypertriglyceridemic subjects (22). Whether the resulting change in ratios of apo C-II to apo C-III or other apolipoproteins might have an influence on triglyceride clearance in vivo is unknown. Conceivably, apo C-II has other roles independent of its relationship to lipoprotein lipase, in which apo $\mathrm{C}-\mathrm{II}_{2}$ may not function normally. Three of our affected patients had one or more of the clinical risk factors for hyperlipidemia, such as marked obesity or glucose intolerance. It is of interest that all four of the hyperlipidemic patients with apo $\mathrm{C}$ - $\mathrm{II}_{2}$ had the apolipoprotein E phenotype E3/2. This phenotype could have influenced the expression of hyperlipidemia in these patients.

Our finding of apparent heterozygosity for apo $\mathrm{C}-\mathrm{II}_{1}$ and $\mathrm{C}-\mathrm{II}_{2}$ in $\sim 12 \%$ of normolipidemic black adults suggests that this is a common trait among individuals of African descent and that it does not appear to be, by itself, a determinant of hyperlipidemia. Whether in the presence of other etiologic factors it could participate in the genesis of hyperlipidemia will require further studies. Perhaps, as with hemoglobin S and some other protein polymorphisms, there has been some positive selection pressure favoring this mutation among Africans, perhaps even relating to one of the roles of lipoproteins that does not involve the transport of triglycerides or cholesterol.

\section{Acknowledgments}

This work was supported by grant HL-14237 (Arteriosclerosis SCOR) from the U. S. Public Health Service. Dr. Menzel was supported by the Deutsche Forschungsgemeinschaft.

\section{References}

1. Havel, R. J., V. G. Shore, B. Shore, and D. M. Bier. 1970. Role of specific glycopeptides of human serum lipoproteins in the activation of lipoprotein lipase. Circ. Res. 27:595-600.

2. Breckinridge, W. C., J. A. Little, G. Steiner, A. Chow, and M. Poapst. 1978. C-II. N. Engl. J. Med. 298:1265-1273.

3. Kane, J. P., T. Sata, R. L. Hamilton, and R. J. Havel. 1975.
Apoprotein composition of very low density lipoproteins of human serum. J. Clin. Invest. 56:1622-1634.

4. Jackson, R. L., H. N. Baker, E. B. Gilliam, and A. M. Gotto, Jr. 1977. Primary structure of very low density apolipoprotein C-II of human plasma. Proc. Natl. Acad. Sci. USA. 74:1942-1945.

5. Hospattankar, A. V., T. Fairwell, R. Ronan, and H. Bryan Brewer, Jr. 1984. Amino acid sequence of human plasma apolipoprotein C-II from normal and hyperlipoproteinemic subjects. J. Biol. Chem. 259:318-322.

6. Jackson, C. L., G. A. P. Bruns, and J. L. Breslow. 1984. Isolation and sequence of a human apolipoprotein CII cDNA clone and its use to isolate and map to human chromosome 19 the gene for apolipoprotein CII. Proc. Natl. Acad. Sci. USA. 81:2945-2949.

7. Myklebost, O., B. Williamson, A. F. Markham, S. R. Myklebost, J. Rogers, D. E. Woods, and S. T. Humphries. 1984. The isolation and characterization of cDNA clones for human apolipoprotein CII. J. Biol. Chem. 259:4401-4404.

8. Havel, R. J., L. Kotite, and J. P. Kane. 1979. Isoelectric heterogeneity of the cofactor protein for lipoprotein lipase in human blood plasma. Biochem. Med. 21:121-128.

9. Pagnan, A., R. J. Havel, J. P. Kane, and L. Kotite. 1977. Characterization of human very low density lipoproteins containing two electrophoretic populations: double pre-beta lipoproteinemia and primary dysbetalipoproteinemia. J. Lipid Res. 18:613-622.

10. Havel, R. J., L. Kotite, J.-L. Vigne, J. P. Kane, P. Tun, N. Phillips, and G. C. Chen. 1980. Radioimmunoassay of human arginine-rich apolipoprotein, apoprotein E. J. Clin. Invest. 66:1351-1362.

11. Myers, L. H., N. R. Phillips, and R. J. Havel. 1976. Mathematical evaluation of methods for estimation of the concentration of the major lipid components of human serum lipoproteins. J. Lab. Clin. Med. 88:491-505.

12. Gross, G. 1967. The cyanogen bromide reaction. Methods Enzymol. 11:238-254.

13. Waterson, R. M., and W. H. Konigsberg. 1974. Peptide mapping of aminoacyl-tRNA synthetases: evidence for internal sequence homology in Escherichia coli leucyl-tRNA synthetase. Proc. Natl. Acad. Sci. USA. 71:376-380.

14. Hirs, C. H. W. 1967. Detection of peptides by chemical methods. Methods Enzymol. 11:325-329.

15. Gershey, E. L., G. Vidali, and V. G. Allfrey. 1968. Chemical studies of histone acetylation. J. Biol. Chem. 243:5018-5022.

16. Light, A. 1967. Leucine aminopeptidase in sequence determination of peptides. Methods Enzymol. 25:253-262.

17. Spackman, D. H. 1967. Accelerated methods. Methods Enzymol. 11:3-15.

18. Havel, R. J. 1982. Familial dysbetalipoproteinemia. Med. Clin. N. Am. 66:319-333.

19. Schroeder, W. A., T. H. J. Huisman, J. R. Shelton, E. F. Kleinhaner, A. M. Dozy, and B. Robberson. 1968. Evidence for multiple structural genes for the gamma chains of human fetal hemoglobin. Proc. Natl. Acad. Sci. USA. 60:537-544.

20. Huisman, T. H. J., W. A. Schroeder, A. Felice, D. Powars, and B. Ringelhann. 1977. An anomaly in the gamma chain heterogeneity of the newborn. Nature (Lond.). 265:63.

21. Kinnunen, P. K. J., R. L. Jackson, L. C. Smith, A. M. Gotto, Jr., and J. T. Sparrow. 1977. Activation of lipoprotein lipase by native and synthetic fragments of human plasma apolipoprotein C-II. Proc. Natl. Acad. Sci. USA. 74:5358-5362.

22. Kane, J. P., and R. J. Havel. 1978. Apoprotein composition of triglyceride-rich lipoproteins in primary mixed hyperlipidemia. Clin. Res. 26:652A. (Abstr.) 